\title{
Comic Indigenous (Bola Kasti) Based Android: The Development Integrate Problem Based Learning
}

\author{
Wafda Nabila Azmy ${ }^{1, *}$ Heru Kuswanto ${ }^{1}$ \\ ${ }^{1}$ Physic Education, Universitas Negeri Yogyakarta, Sleman, Indonesia \\ *Corresponding author.Email: wafdanabila.2018@student.uny.ac.id
}

\begin{abstract}
The research aims to determine the feasibility of indigenous comics (ball kasti) based on android integrated problem based learning (PBL) in physics learning. Media development using the 4D model which consists of define, develop, design, and disseminate. The feasibility test is obtained through expert validation and limited testing. the items from the limited test before being given to students, first the contents are validated by the instrument validator. The results of expert validation consisting of media and material experts fall into the very good category, as well as the limited test results using a student response questionnaire that are also in the very good category. The developed comics have the characteristics of PBL model learning (orientation of students on problems, organizing students in learning, guiding individual/group experiences, developing and presenting work, analyzing and evaluating problem solving) so that students are more active in learning, so that comics worth using. This is evidenced by the results of the product on the material and media aspects which are included in the very good category, with the proportion of the successive average values of $93.08 \%$ and $93.42 \%$. And also the results of student responses that are included in the good category with an average proportion of $95.92 \%$ production results.
\end{abstract}

Keywords: Comic Indigenous (bola kasti), PBL, Physics Learning.

\section{INTRODUCTION}

Archipelago thinking, local wisdom, and Indonesian education are complex and dynamic characteristics of Indonesia based on the ethnicity that has settled in Indonesia for several centuries and the foreign cultures of India, Arabic, Dutch, Chinese, and others. The synthesis of this mixed culture has caused the Nusantara people, then and now, to have a certain perception of the reality of life. To maintain this, it is necessary to preserve culture and sustainable wisdom [1] [2]. One way to maintain it is by including it in the children's education process, from teaching materials to learning models [1] [3]. In physics lessons, this is done several times by integrating local wisdom learning in class material [4] [8] [11]. Various customs ranging from community habits or just games that are usually played are integrated to get a learning system that is easier for students. As a result, many students were helped and were more critical and understood better in explaining the learning material presented [5] [11] [10] [14]. The extent of custom that develops in the community makes educators more flexible in integrating this in learning. The educational values that are contained in the indigenous and are not yet known by the wider community, become one of the big homework for teachers to be used in the broad learning process [2][14]. For example, in the case of traditional games, there are still many teachers who have not analyzed and observed the value of education. One of the traditional games that can be raised is bola kasti. If seen, the game of bola kasti has values of knowledge about how the ball can be controlled by the hull of the ship. By combining the concept of parabolic motion and the bola kasti game that students usually play, the delivery of knowledge becomes more interesting and easily understood by students.

Science and science and technology are new breakthroughs that can be used in the development of learning media. The use of appropriate and appropriate criteria in the application of learning media can be used to support learning that is facts, concepts, principles or generalizations, practical and durable, easy to use by teachers, right on target and of good quality. By utilizing an android media application that can be accessed more flexibly anywhere and anytime [4], media that contains various interesting features also prevents students from feeling bored and more enthusiastic in learning [5]. The presentation of media that is easier and more interactive 
is an attraction and a separate strategy for teachers and students in learning.

Cellular-based learning is a learning activity using a smartphone, personal digital assistant (PDA), laptop, or other mobile device in transferring knowledge and knowledge [6] [7]. Mobile-based learning allows educators and students to use new innovations that allow students to improve their learning abilities, here comics based on android are a good breakthrough. [8] [9]. Comics consist of a hybrid art form derived from graphic arts and mostly made using print technology, but with the development of technology nowadays comics can be enjoyed in the form of Android-based webcomics [10] [11]. Not limited by page and grid constraints, digital comic narratives are free to define the parameters of the story into a comic "book" (although books are used here in the loosest sense) [12] [13]. The development of a comic story line that contains the delivery of teaching material in a more attractive manner can improve students' abilities in learning [5] [8] [11]. Indigenous (bola kasti) as a habit that has existed in society can be an interesting thing to include as a source of comic storylines. Stories that are packaged with everyday plot plots can make it easier for students to imagine the knowledge they get in the real world.

In the learning process, students are expected to focus more on cognitive understanding, develop the ability to transfer knowledge, apply learning outcomes, analyze problems, and evaluate learning outcomes [14] [15]. The cognitive comprehension skills and skills include higher order mental skills, problem solving skills, and communication skills [16] [17]. Higher Order Thinking Skill (HOTS) is the ability to think at a higher level in the development of 21 st century learning which consists of critical, creative, logical, reflective and metacognitive thinking skills. This is so that students can become problem solvers [18] [19]. One of the learning models that is suitable to support the development of this ability is the problem based learning (PBL) model. By integrating the PBL learning model in an android-based indigenous comic (ball kasti) students can learn how to solve problems critically, express their opinions verbally, and produce the right solution to a problem [21]. PBL requires students to think for themselves to critically analyze each argument.

The comic that was developed contains traditional lines (bola kasti) as one of the traditional games that have been developing in society for a long time. The flow is integrated with the PBL learning model which is guided by the teacher so that students become good problem solvers and remain in the correct perception of learning according to the teacher's guidance. To support this, the use of concrete images and simple language is one way so that students' perceptions are not too different from one another. To make it more attractive and accessible, comics are made in the form of an Android-based webcomic. This is so that learning can not only be done at school during school hours, but can also be accessed anywhere and anytime.

\section{METHODS AND RESEARCH}

Development of indigenous comics (bola kastis) based on integrated Android based PBL was carried out using the 4D development model. With this model comic are developed through validation tests and limited testing at each stage.

\subsection{Define:}

Analyzing the conditions of students and teachers in the classroom, analyzing class needs according to the curriculum used, analyze the use of smartphone devices in the classroom, and analyzing students' indigenous knowledge. This stage is carried out by observation, documentation, and class interviews.

\subsection{Design:}

Based on the define stage, the media will be designed. The material is formulated based on the indigenous used, then the storyboard is compiled as the initial design of the learning media.

\subsection{Develop:}

Media was developed with corel draw X7 and sigil, then transformed into a mobile android application that can be accessed anywhere, anytime. At this stage the validity test and limited test began to be carried out. The validity test consists of material and media validation. After being tested, the product is then revised according to the evaluation and suggestions of each test. The test at this stage is carried out in order to produce suitable media for use in learning.

\subsection{Disseminate:}

Appropriate media is then disseminated.

The product feasibility assessment is carried out to determine the feasibility of the product developed from material and media experts, while the response questionnaire assessment is carried out to determine the student's response to the product developed. Assessment is done by using a percentage

$P=\frac{f}{N} 100 \%$

In equation $1 \mathrm{P}$ is the result of the assessment presentation, $\mathrm{f}$ is the percentage of the tuned frequency, while $\mathrm{N}$ is the total data. The criteria for presentation results can be grouped as shown in Table 1 
Table 1. Feasibility criteria of the product

\begin{tabular}{|c|c|}
\hline Score of & Criteria \\
assessment/questionnaire & \\
\hline $\mathbf{8 0} \%-\mathbf{1 0 0} \%$ & Verry Good \\
$\mathbf{6 0} \%-\mathbf{7 9 . 9 9} \%$ & Good \\
$\mathbf{5 0} \%-\mathbf{5 9 . 9 9} \%$ & Enough \\
$\mathbf{4 0} \%-\mathbf{4 9 . 9 9} \%$ & Not Enough \\
\hline
\end{tabular}

\section{RESULT AND DISCUSSION}

The product resulting from the development is an adroid-based indigenous comic (ball kasti) with an integrated storyline of PBL learning model. Development using the 4D model. The product being developed is tested for its feasibility by using the media and material feasibility test, as well as the response to its use using a student response questionnaire. The following describes an explanation of the development stages and the results of the product feasibility test with the 4D floating model.

\subsection{Result of the analysis stage}

The development design of indigenous comics based on integrated android based PBL can be observed in table 2.

Table 2. Result Analysis of comic development needs

\begin{tabular}{|c|c|}
\hline Needs & Result \\
\hline $\begin{array}{l}\text { Feature that according to } \\
\text { the approach }\end{array}$ & $\begin{array}{l}\text { Comics, video, sheets } \\
\text { discussion }\end{array}$ \\
\hline $\begin{array}{ll}\text { Software } & \text { for } \\
\text { development } & \end{array}$ & $\begin{array}{l}\text { CorelDraw } \times 7 \text { and } \\
\text { android studio }\end{array}$ \\
\hline $\begin{array}{l}\text { Material that according } \\
2013 \text { curriculum revision }\end{array}$ & $\begin{array}{l}\text { Parabolic motion } \\
\text { students are able to be }\end{array}$ \\
\hline $\begin{array}{l}\text { Characteristics of high } \\
\text { school students }\end{array}$ & $\begin{array}{l}\text { problem solvers in } \\
\text { solving a problem }\end{array}$ \\
\hline
\end{tabular}

\subsection{Result of the design stage}

The design is developed using PBL syntax. Its use in comics can be seen in table 3 .

Table 3 Integration of PBL steps on Android-based Indigenous Comics (Bola Kasti)

\begin{tabular}{|l|l|}
\hline PBL Activity & Steps \\
\hline Student & Students are given initial motivation \\
orientation to & before learning by watching the \\
the problem & $\begin{array}{l}\text { video displayed on indigenous } \\
\text { comic media (Bola Kasti) }\end{array}$ \\
\hline
\end{tabular}

\begin{tabular}{|l|l|}
\hline $\begin{array}{l}\text { Organizing } \\
\text { students to } \\
\text { study }\end{array}$ & $\begin{array}{l}\text { Teacher Helping students to use } \\
\text { indigenous comic media (Bola } \\
\text { Kasti) in the learning process }\end{array}$ \\
$\begin{array}{l}\text { Guiding } \\
\text { individual / } \\
\text { group } \\
\text { experiences }\end{array}$ & $\begin{array}{l}\text { Comics are packed with stories that } \\
\text { contain information, experiments, } \\
\text { and explanations of a solution to a } \\
\text { problem contained in the Bola Kasti } \\
\text { game. All these things can be found } \\
\text { by students individually or in groups }\end{array}$ \\
$\begin{array}{l}\text { Develop and } \\
\text { present the } \\
\text { work }\end{array}$ & $\begin{array}{l}\text { From the observation of the } \\
\text { problems presented in the } \\
\text { indigenous comic (Bola Kasti), } \\
\text { students present their observations } \\
\text { in a report. }\end{array}$ \\
$\begin{array}{l}\text { Analyze and } \\
\text { evaluate the } \\
\text { problem } \\
\text { solving } \\
\text { process }\end{array}$ & $\begin{array}{l}\text { Students report their observations } \\
\text { by means of presentations, and the } \\
\text { teacher helps to reflect or evaluate } \\
\text { the results of these observations. }\end{array}$ \\
\hline
\end{tabular}

The comic that was developed was called komiku parabola. This name was chosen from Indonesian, which means my comic is parabola. The choice of name was made to attract students' interest and curiosity in studying the comic media that had been developed. From this goal it is hoped that students can be more enthusiastic in learning physics lessons. Parabolic Komiku is presented with a typical traditional bola kasti game flow with the addition of planting material about parabolic motion in it. Conversations in comics are converted into casual everyday conversations so that it can make it easier for students to understand the material.

The story line is designed for students to understand the condep themselves described in the story, so that students can independently learn and understand the meaning of the material presented. 


\subsection{Result of the development stage}

Development is carried out according to the storyboard that has been made in the design stage. The development was carried out with the help of the Corre Draw X7 and sigil applications. The resulting product is an EPUB which can be accessed using the Moon Reader application or other EPUB readers. The main comic display menu can be seen in Figure 1

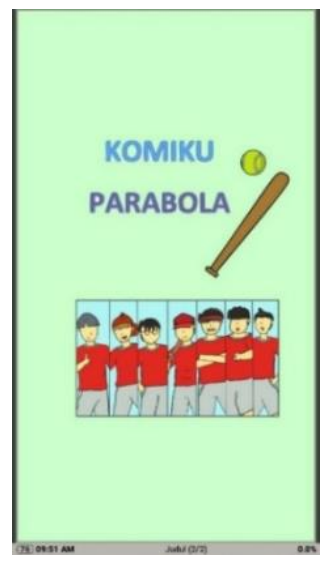

Figure 1. Main Menu

Figure 2. Apperception video

The reception video in Figure 2 contains a video about the game of bola kasti. The video is shown to bring up students' initial thoughts about bola kasti.
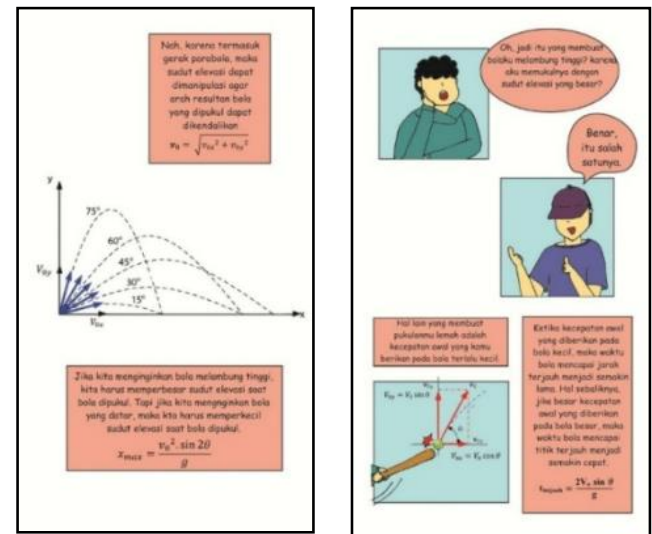

Figure 3. Feature "indigenous comic (bola kasti) based on android integrated PBL"

Figure 3 is a scene that contains an explanation of parabolic motion material in the form of a story. Comics consist of several pages that are divided into episodes. To read the next page, you only need to scroll up and down, or to the right. If it is not clear, the display can also be enlarged or reduced as needed.

Table 4. Result of Product Assessment in Material Aspects

\begin{tabular}{|c|c|c|}
\hline Rated aspect & $\begin{array}{c}\text { Score } \\
(\%)\end{array}$ & Criteria \\
\hline Learning & $94,08 \%$ & Very good \\
\hline
\end{tabular}

\begin{tabular}{|c|c|c|}
\hline $\begin{array}{c}\text { Completeness of } \\
\text { Contents }\end{array}$ & $89,25 \%$ & Very good \\
Theory & $95,25 \%$ & Very good \\
\hline Average & $93,08 \%$ & Very good \\
\hline
\end{tabular}

Table 4 shows that the results of the product assessment in the material aspect are included in the very good category with an average value percentage of $93.08 \%$. These results indicate that comics in terms of material are suitable for use in learning physics. The completeness of the contents needs improvement so that the material presented in the comics is more complete and easy to understand.

Table 5. Result of Product Assessment in Media Aspect

\begin{tabular}{|l|c|l|}
\hline \multicolumn{1}{|c|}{ Rated aspect } & Score (\%) & Criteria \\
Lontent Quality & $100 \%$ & Very good \\
Implementation & $92,83 \%$ & Very good \\
Design & $89,25 \%$ & Very good \\
Visual Appearance & $91,67 \%$ & Very good \\
\hline Average & $93,75 \%$ & Very good \\
\hline
\end{tabular}

Table 5 shows that the assessment of the product in the media aspect is also very good with an average percentage rating of $93.75 \%$. These results indicate that comics are feasible in terms of media assessment. As for the results of the analysis, there is still a need for improvement in the comic design section. Improvements need to be made so that the appearance of the comics is more attractive and makes students more enthusiastic in learning.

From the results of the overall assessment, it was found that the average percentage of the results of the assessment of media and material was in the very good category with a value of $93.42 \%$. These results indicate that comics in terms of media and material are feasible based on research [10] [11].

\subsection{Result of the implementation stage}

The implementation stage was carried out on 31 students of class X MIPA. The analysis results are presented in table 6 . 
Table 6. Results of Product Assessment in the Medical Aspect of the students' responses

\begin{tabular}{|l|c|l|}
\hline \multicolumn{1}{|c|}{ Rated aspect } & Score (\%) & \multicolumn{1}{|c|}{ Criteria } \\
\hline Attraction & $100 \%$ & Very good \\
Theory & $95 \%$ & Very good \\
Language & $92,83 \%$ & Very good \\
\hline Average & $95,92 \%$ & Very good \\
\hline
\end{tabular}

Table 6 shows the responses of students who are also in the good category with an average percentage of assessment results of $95.92 \%$ according to the study [10]. The results of the analysis showed that the indigenous comic (bola kasti) was attractive to students with a percentage of the attraction value of $100 \%$. Comics which are packed with theory and light language also make it easier for students to learn. Thus the indigenous comic (bola kasti) based on integrated android PBL can support students' learning, especially in the material of parabolic motion.

\subsection{Result of evaluation stage}

In the evaluation stage, improvements are made based on suggestions and input given by students as student product users during the implementation stage. Some suggestions given include improving the quality of the image so that it does not break and writing words. The revision made at this stage is an improvement of some of the students' suggestions so that the media developed is better and easier to understand.

\section{CONCLUSION}

The indigenous comic (bola kasti) based on integrated android PBL is worthy for use in physics learning. Eligibility is based on the assessment of the appropriateness of media experts, materials, and student response questionnaires which fall into the very good category. The PBL model that is integrated in comics can make students more enthusiastic about being good problem solvers in learning. The native comics of the android-based integrated PBL bola kasti games which are already feasible can be used as a learning medium in parabolic physics material in the classroom.

\section{REFERENCES}

[1] Leo, A. S. (2015). Development of Local WisdomBased Social Science Learning Model with. Bengawan Solo as the Learning Source. American International Journal of Social Science Vol. 4, No. $4,51-58$
[2] Hartini, S., S. Firdausi, Misbah, dan N. F. Sulaeman. (2018). The Development of Physics Teaching Materials Based on Local Wisdom to Train Saraba Kawa Character. Jurnal Pendidikan IPA Indonesia 7 (2) (2018) 130-137 https://doi.org/10.15294/jpii.v7i2.14249

[3] Saputra, M. R. D. \& H. Kuswanto. (2018). Development of Physics Mobile (Android) Learning Themed Indonesian Culture Hombo Batu on the Topic of Newton's Law and Parabolic Motion for Class X SMA/MA . Journal of Physics: $\begin{array}{lllll}\text { Conf. } & \text { Series } & 1097 & \text { (2018) } & 012023\end{array}$ https://doi.org/10.1088/17426596/1097/1/012023

[4] Hadi \& Dwijananti. (2015). Pengembangan Komik Fisika Berbasis Android Sebagai Suplemen Pokok Bahasan Radioaktivitas untuk Sekolah Menengah Atas. Unnes Physics Education Journal. 4 (2) (2015). ISSN 2252-6935

[5] Priyadi, A. N. W.,H. Kuswanto, \& Sumarna. (2019). Android Physics Comics to Train The Mathematical Representation Ability on Momentum and Impulse of Senior High School Students. Journal of Physics: Conference Series 1440 (2020) 012041 https://doi.org/10.1088/17426596/1440/1/012041

[6] Adi, N. P., Yulianto, R. A., Irwan, M., \& Endris, W. M. (2016). The Effectiveness of Android Application as a Student Aid Tool in Understanding Physics Project Assignments. Proceedings of the 2nd International Seminar on Science Education (ISSE) (pp. 173-178).

[7] Husna, M. \& H. Kuswanto. (2018). Development of Physics Mobile Learning Based on Local Wisdom to Improve Vector and Diagram Representation Abilities. International Journal of Interactive Mobile Technologies (iJIM) - eISSN: 1865-7923 Vol. 12, No. 6, 2018 https://doi.org/10.3991/ijim.v12i6.8746

[8] Damayanti, A. E. \& H. Kuswanto. (2019). The use of android-assisted comics to enhance students' critical thinking skill. Journal of Physics: $\begin{array}{llll}\text { Conference Series } 1440 & \text { (2020) } & 012039\end{array}$ https://doi.org/10.1088/17426596/1440/1/012039

[9] Azmy, W. N., A. E. Damayanti, H. Kuswanto \& B. Susety. (2019). Learning optics with androidassisted comics: the impacts on students critical thinking. Journal of Physics: Conference Series $1440 \quad$ (2020) 012055. https://doi.org/10.1088/17426596/1440/1/012055

[10] Rahayu, M. S. I. \& H. Kuswanto. (2019). Development of android-based comics integrated with scientific approach in physics learning. Journal of Physics: Conference Series 1440 (2020) 012040 6596/1440/1/012040 https://doi.org/10.1088/1742-

[11] Handayani, D. P., Jumadi, I. Wilujeng, \& H. 
Kuswanto. (2019). Development of Comic Integrated Student Worksheet to Improve Critical Thinking Ability in Microscope Material. Journal of Physics: Conf. Series 1233 (2019) 012069 https://doi.org/10.1088/17426596/1233/1/012069

[12] Cook, M. P. \& J. S. J. Kirchoff. (2017). Teaching Multimodal Literacy Through Reading and Writing Graphic Novels. Language and Literacy Volume 19, Issue 4

[13] Kirchoff, Jeff. (2017). Using Digital Comics to Develop Digital Literacy:Fostering Functionally, Critically, and Rhetorically Literate Students. Texas Journal of Literacy Education Vol.5, Issue 2

[14] Puspita I, I Kaniawati \& I R Suwarma (2017). Analysis of Critical Thinking Skills on The Topic of Static Fluid. Journal of Physics: Conf. Series. 895. $5 \quad$ https://doi.org/10.1088/17426596/895/1/012100

[15] Hadi, SA., Susantini E., \& Agustini R. (2018). Training of Students' Critical Thinking Skills through the implementation of a Modified Free Inquiry Model. Journal of Physics: Conf. Series Vol 947, p. 012063

[16] Wartono, W., M. N. Hudha, \& J. R. Batlolona. (2018). How Are The Physics Critical Thinking Skills of The Students Taught by Using InquiryDiscovery Through Empirical and Theorethical Overview. EURASIA Journal of Mathematics, Science and Technology Education. 14(2):691697. https://doi.org/10.12973/ejmste/80632

[17] Fery Hadi Sutrisno, S. K. Handayanto, E. Supriana, \& R. Laksmisari. (2018). How Does The Students' Critical Thinking Ability in Geometry Optics?. Unnes Science Education Journal vol 7 (2). https://doi.org/10.15294/USEJ.V7I2.24297

[18] Putranta, H. \& H. Kuswanto, (2018). Improving Students' Critical Thinking Ability Using Problem Based Learning (PBL) Learning Model Based on PhET Simulation. SAR Journal. Volume 1, Issue 3, Pages 77-87, ISSN 2619-9955 https://doi.org/10.18421/SAR13-02

[19] Putri, S. D. \& D. Djamas. (2017). Penerapan Model Pembelajaran Problem Based Learning (PBL) untuk Meningkatkan Hasil Belajar Peserta Didik SMA pada Materi Usaha dan Energi. Jurnal Ilmiah Pendidikan Fisika Al-Biruni, 06 (1) (2017) 125-135. https://doi.org/10.24042/jpifalbiruni.v6i1.64

[20] Widianingtiyas, L., Siswoyo, \& F. Bakri. (2015). Pengaruh Pendekatan Multi Representasi dalam Pembelajaran Fisika Terhadap Kemampuan Kognitif Siswa SMA. Jurnal Penelitian \& Pengembangan Pendidikan Fisika Volume 1 Nomor 1. https://doi.org/10.21009/1.01105

[21] Putri, S. D. \& D. Djamas. (2017). Pengembangan Perangkat Pembelajaran Fisika Berbasis Keterampilan Berpikir Kritis dalam Problem-
Based Learning. Jurnal Ilmiah Pendidikan Fisika Al-Biruni, $06 \quad$ (1) (2017) 125-135. https://doi.org/10.24042/jpifalbiruni.v6i1.64 